\title{
Molecular and Biochemical Characterization of Some Egyptian Genotypes Rhizobium (Vicia Faba) Isolates
}

Elzanaty AM, Hewedy OA*, Nagaty HH and Abd Elbary MI

Genetics Department, Faculty of Agriculture, Minoufiya University, Shibin El-Kom, Egypt

\begin{abstract}
Thirteen Rhizobial isolates were recovered from the root nodule of Faba bean (Viciae faba L.) grown in different geographic locations and soil properties in Egypt. The tested isolates were identified as R. leguminosarum sv. Viciae on the bases of morphological, biochemical characteristics and sequences of the gene encoding 16s rRNA. Rhizobium isolates were tested for their ability to utilize different carbon sources. Mannitol and Glucose were the best source of carbon. All tested isolates from Vicia faba differ in IAA production. The maximum amount of IAA production was in the range of $(2.04 \mu \mathrm{g} / \mathrm{ml})$ for Al Arish isolate to $(7.5 \mu \mathrm{g} / \mathrm{ml})$ for Ismailia isolate among the studied isolates. A great ability to degrade Roundup herbicide among the tested isolates was observed. Sues City isolate was the best active degrading Roundup herbicide on plates. All of the tested isolates showed resistances to (25 and $50 \mathrm{mg} / \mathrm{ml}$ ) expect isolate RL7 was sensitive at high Roundup herbicide concentration, while isolates RL5, RL6, RL8, RL10 and RL13 were the most tolerance at $50 \mathrm{mg} / \mathrm{ml}$ herbicide. South Sinai, Zefta, Rafah, El-Menia, Cairo and Ismailia isolates shared a common band with mol. wt. of $70 \mathrm{KDa}$. New protein types were detected due to the differential response of the five isolates to the effects of the environment stress.
\end{abstract}

Keywords: Faba bean; Carbon sources; IAA; Herbicide tolerance; Protein pattern; 16s rRNA

\section{Introduction}

Bacteria belonging to the genera Allorhizobium, Azorhizobium, Bradyrhizobium, Mesorhizobium, Rhizobium and Sinorhizobium [1] are generally called Rhizobia. They are best known for their ability to establish symbiotic relationships with leguminous plants of agricultural and environmental importance, a process that results in biological nitrogen fixation [2]. Nitrogen-fixing leguminous increase soil fertility and quality by enhancing soil $\mathrm{N}$ content, organic matter and soil aggregates [3]. Fundamentally, nitrogen $(\mathrm{N})$ is one of the most vital nutrients required for the synthesis of the vast array of metabolites such as proteins, enzymes, chlorophyll, and nucleic acids and consequently, determines critically the health of all living organisms including microbes and plants [4,5]. Despite of the presence of this element in the atmosphere in huge amounts (78\%), the growing plants cannot utilize it in the present gaseous form (N2). For this, the nitrogen fixing microorganisms residing in the specific organs of root systems of leguminous plants have devised a novel strategy to convert the plant-unavailable atmospheric $\mathrm{N} 2$ into plant-utilizable forms (ammonia) through biological N2 fixation (BNF) using enzymatic machinery known as nitrogenase [6]. BNF represents an economically beneficial and environmentally sound alternative to chemical fertilizers [7]. More than $50 \%$ of the applied of nitrogen fertilizers are somehow lost through different processes which not only represent a cash loss to the farmers but also consequently polluted the environment. Scientists all over the world are facing this alarming situation and they are trying to overcome this condition by exploring alternative sources which are cost effective and save the environment. Biofertilizer, an alternative source of $\mathrm{N}$, especially rhizobia in legume symbiosis, is a promising technology. The United Nations Food and Agriculture Organization (FAO) estimates that the total demands for agricultural products will be $60 \%$ higher in 2030 than present time and more than $85 \%$ of this additional demand will come from developing countries. For over half a century, the world has relied on increasing crop yields to supply an ever increasing demand for food. Pesticides accumulation into soils at an abnormal level causes spectacular changes in composition, diversity and functional activities of important soil microflora [8]. Round up causes decreased nodule numbers and their dry weight in cowpea roots with no nodule development on side [9]. Generally Pesticides also interact with rhizosphere microorganisms including rhizobia and restrict the root growth, in that way lead to the reduction in the number of the root sites available for the rhizobial infection [10]. Also decreases the total microbial biomass not only adversely affect the growth of bacteria, fungi and actinomycetes [11] by inhibiting protein synthesis, the metabolic enzymes including dehydrogenase and phsphatase. In addition to damaging structural proteins through biochemical alterations in membrane composition and geno-toxicity [12]. Pesticides are divided into categories according to the target organisms they are designed to control e.g., herbicides are used to kill unwanted weeds; insecticides control insects and fungicides eradicate phyto-pathogenic fungi. Pesticides are also classified according to their chemical structures or on the basis of their modes of action (Figure 1). Pesticides inhibit symbiotic signaling between host plants and rhizobia by interfering in the interaction between plant-secreted flavonoids and the rhizobial NodD proteins; thus they effectively block molecular communication and disrupt the initiation of symbiosis [13]. In addition, pesticides not only inhibit the biochemical signaling between the hosts and cognate rhizobia but also block the initial attachment of complementary rhizobia to lectins present on root hairs as the recognition sites by protecting them [14]. Herbicides may have negative effects on growth of rhizobia [15]. Protein profiles [16]

*Corresponding author: Hewedy OA, Genetics Department, Faculty of Agriculture, Minoufiya University, Shibin El-Kom, Egypt, Tel: 00201223570768 E-mail: hewedy.omar@gmail.com

Received: October 16, 2014; Accepted: March 01, 2015; Published: March 08 2015

Citation: Elzanaty AM, Hewedy OA, Nagaty HH, Abd Elbary MI (2015) Molecular and Biochemical Characterization of Some Egyptian Genotypes Rhizobium (Vicia Faba) Isolates. J Bioengineer \& Biomedical Sci 5: 145. doi:10.4172/21559538.1000145

Copyright: (C) 2015 Elzanaty AM, et al. This is an open-access article distributed under the terms of the Creative Commons Attribution License, which permits unrestricted use, distribution, and reproduction in any medium, provided the original author and source are credited. 


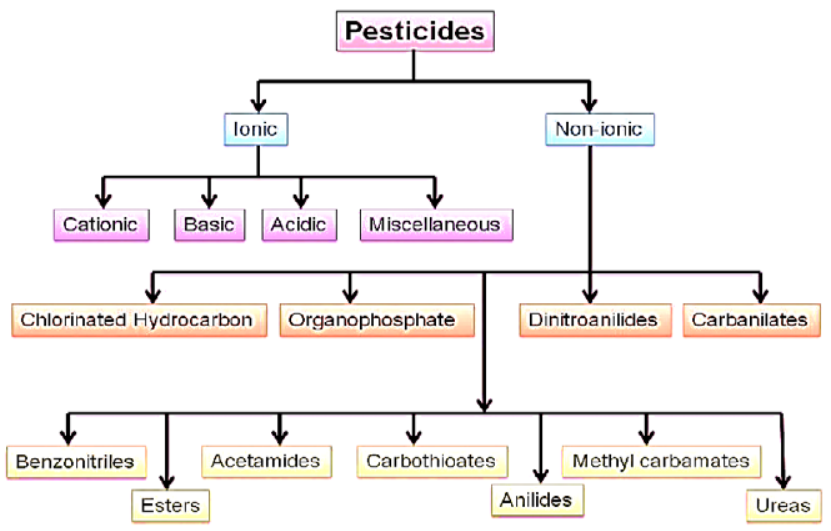

Figure 1: Classification of pesticides on the basis of chemical structures.

\begin{tabular}{|l|l|}
\hline Isolate No. & locations \\
\hline Rh1 & Quesna City, Al Menoufeya Governorate. \\
\hline Rh2 & Banha City, Al Qalyoubeya Governorate. \\
\hline Rh3 & Sadat City, Al Menoufeya Governorate. \\
\hline Rh4 & Zefta City, Al Gharbeya Governorate. \\
\hline Rh5 & Beni Suef City, Beni Suef Governorate. \\
\hline Rh6 & Sues City, Al Sues Governorate. \\
\hline Rh7 & South Sinai City, South Sinai Governorate. \\
\hline Rh8 & Al Arish City, North Sinai Governorate. \\
\hline Rh9 & Rafah City, North Sinai Governorate. \\
\hline Rh10 & New Al Menia City, AL Menia Governorate. \\
\hline Rh11 & Moshtohor City, Al Qalyoubeya Governorate. \\
\hline Rh12 & Cairo City, Cairo Governorate. \\
\hline Rh13 & Ismailia City, Al Ismailia Governorate. \\
\hline
\end{tabular}

Table 1: locations of Rhizobium leguminosarium sv. Viciae isolates.

have been studied in rhizobia. Proteins induced in response to stress may suggest that they have an important role in homeostasis and maintenance of vital cellular functions [17]. The SDS-PAGE analysis of whole cell proteins not only helps in identifying of the Rhizobial strains $[18,19]$ but also useful in the differentiation among the isolates within the same group [20]. Also molecular tools for the identification of bacteria are now available and are used routinely in laboratories. The electrophoretic screening of large plasmids, although limiting the analysis to the extra chromosomal elements, has a particular importance in the screening of Rhizobium. These bacteria have large plasmids ( $>50 \mathrm{~kb}$ in size) that account for a substantial portion of their genome and contain several genes coding for nodulation and nitrogen fixation [21]. These plasmids are often present in variable numbers and sizes; traits that provide the basis for an accurate strain characterization when the extracted plasmids are separated by gel electrophoresis [22]. The principle objectives of this study are isolation and evaluation the genetic diversity of some root-nodule bacteria isolates from Faba bean plants grown in different geographic locations in Egypt based on morphological, biochemical and molecular characteristics to determine the biodiversity among tested isolates. In addition, plasmid profile and herbicide tolerance.

\section{Material and Methods}

\section{Collection and isolation of Rhizobium isolates}

Thirteen representative sites were chosen from ten Egyptian governorates as presented in Table 1 and Figure 2. Rhizobial isolates collected from the root nodules of Faba bean (Vicia faba L.) plants. Plant roots containing several nodules from each plant and transported in plastic bags (each plant in a separate bag). Bacteria were generally isolated in the same day as plant harvesting.

\section{Isolation of rhizobium isolates}

All nodules were cut off in a laminar flow cabinet with small pieces of root and washed thoroughly with $2.5 \% \mathrm{NaOCl}$ and sterile water. Nodules were surface sterilized with $70 \%$ ethanol alcohol for $5 \mathrm{~min}$ and exhaustively washed in sterile distilled water. After washing the root nodules were taken from the roots with care not to damage the surface, washed thoroughly in distilled water. Nodules were then transferred to $0.2 \%(\mathrm{~W} / \mathrm{V})$ solution of mercuric chloride for 3-5 minutes. Each nodule was crushed under aseptic conditions and streaked onto a Yeast-Mannitol Agar plate (YMA) using a sterile loop and incubated at $28^{\circ} \mathrm{C}$. Single colonies were picked up from the original streaked plates. Pure cultures of Rhizobium leguminosarum were isolated according to [23] methods and restreaked on YMA containing Congo red to ensure purity before storage in $20 \%$ glycerol at $-20^{\circ} \mathrm{C}$. Stock cultures of the Rhizobium isolates were maintained on slants of YEM at $4^{\circ} \mathrm{C}$ and refreshed periodically.

\section{Purification and storage of rhizobium isolates}

Agar plates were incubated at $28 \pm 1^{\circ} \mathrm{C}$ for 3 days. Individual colonies appearing over this period were re-streaked onto YEMA plates, and stored at $4^{\circ} \mathrm{C}$ until the time of processing.

\section{Phenotypic characteristics}

Antibiotic resistance pattern: All isolates were evaluated for their responses as resistant or sensitive against 24 different antibiotic disks [24]. Growth rate at different carbon source: All of the Rhizobia isolates were tested for utilization of different carbon sources by replacing mannitol in YEM broth medium with equal amounts of different carbon sources including glucose, fructose, mannose, and maltose to study the effect of different carbon sources on growth of isolates. The growth was measured after $24 \mathrm{~h}$ and $48 \mathrm{~h}$ of incubation at $28 \pm 1^{\circ} \mathrm{C}$.

\section{Roundup herbicide resistance test by agar plate and broth medium}

Laboratory experiment: The sensitivity or resistance of herbicide on growth of Rhizobium was determined by two methods.

YEMA: The effect of Roundup on R. leguminosarum isolates under laboratory conditions were studied on Petri dishes containing YEM agar. In the first method bacterial sensitivity streak plate method, the

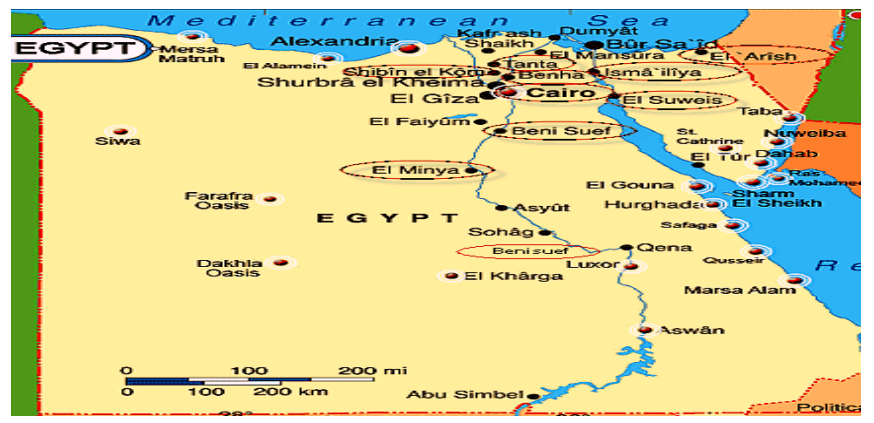

Figure 2: locations of Rhizobium leguminosariumsv. Viciae isolates. 
calculated amount of herbicide was mixed with YEMA medium and poured into sterile Petri plates. Plates without herbicide were prepared to use as control. Plates were streaked with broth suspension 107cells $\mathrm{ml}^{-1}$ of test organism. The plates for Rhizobium were incubated at $28^{\circ} \mathrm{C}$ for 4 days, after which growth was examined. Growth was visually grouped into 4 categories: +++ (good), ++ (moderate), + (poor) and-(no growth) at different concentration of $0,25,50,100 \mathrm{mg} / \mathrm{ml}$ respectively. Three replicates of Petri dishes were used to each isolate as well as three Petri dishes were used without Roundup as control. The Petri dishes were incubated at $28^{\circ} \mathrm{C}$. After 4 days, were inspected to estimate the efficacy of Roundup against Rhizobium isolates.

YEM broth: The second method was bacterial sensitivity broth culture method in $150 \mathrm{ml}$ flasks containing $50 \mathrm{ml}$ YEM, $\mathrm{pH}$ of medium was adjusted to 7 , and the control cultures were grown at $28^{\circ} \mathrm{C}$. The flasks were incubated on rotary shaker for 4 days at $180 \mathrm{rpm}$. The growth of rate in Rhizobial isolates was measured by recording optical density (OD). The experiment was conducted in three replicates. The turbidity was measured using Jenway UV-VIS. spectrophotometer model UV6305 at $600 \mathrm{~nm}$ against the blank (sterilized uninoculated YEM broth) and the mean generation time was calculated for each isolates.

\section{Biochemical identification of rhizobia}

IAA production: All the isolates were tested to IAA production in Yeast Extract Mannitol (YEM) broth [23] supplemented with $100 \mu \mathrm{g} /$ $\mathrm{ml} \mathrm{L}$-tryptophan and added to YEM medium without L-tryptophan. The test tubes were covered with brown paper and incubated at $28^{\circ} \mathrm{C}$ for 5 days on a rotary shaker. The broth was centrifuged at 3,000 rpm for 30 minutes. $2 \mathrm{ml}$ of supernatant was collected and 2-3 drops of o-phosphoric acid were added. The aliquots were shaken and $4 \mathrm{ml}$ of Salkowski reagent $(1 \mathrm{ml}$ of 0.5$) \mathrm{M} \mathrm{FeCl}_{3}$ in $50 \mathrm{ml}$ of $35 \%$ perchloric acid $\left(\mathrm{HClO}_{4}\right)$ was added then vortexes thoroughly. The samples were incubated at room temperature for 25 minutes. Development of a pink color indicates IAA production. IAA concentrations were quantified by Spectrophotometer, the developed pink color from previous reagent was read at $530 \mathrm{~nm}$ using spectrophotometer, and concentration of produced IAA was determined from a prepared standard curve of pure IAA $\left(10-100 \mu \mathrm{gml}^{-1}\right)$ [25]. Uses different IAA concentrations are prepared as aqueous solution of IAA ranging from $10 \mathrm{microgram} / \mathrm{ml}$ to 100 micrograms $/ \mathrm{ml}$, each $1 \mathrm{ml}$ of the standard, $2 \mathrm{ml}$ of $2 \% 0.5 \mathrm{M} \mathrm{FeCl}_{3}$ in $35 \%$ perchloric acid (Salkowaski) reagent is added and readings are taken after 25 minutes at $530 \mathrm{~nm}$ by UV-Visible spectrophotometer.

Catalase test: The catalase enzyme decomposes hydrogen peroxide $\left(\mathrm{H}_{2} \mathrm{O}_{2}\right)$ to water and $\mathrm{O}_{2}$. Hydrogenperoxide is very toxic for bacteria. Bacteria are smeared in a drop of hydrogen peroxide and checked for formation of oxygen gas bubbles.

Protein profile: Sodium dodecyl sulphate polyacrylamide gel electrophoresis (SDS-PAGE) Glass slabs and spacers were washed with water and wiped with tissue paper. Rizobia were grown on yeast extract mannitol broth [23] at $28^{\circ} \mathrm{C}$ for three days. According to [16] protein was extracted, Sodium dodecyl sulfate (SDS) polyacrylamide gel electrophoresis (PAGE) as described previously [26].

\section{DNA extraction and amplification of 16S rRNA Gene of rhizobia}

DNA was extracted from bacterial cultures using SDS/CTAB Lysis and phenol/chloroform extraction method [27]. Sequence analysis of $16 \mathrm{~S}$ rDNA and subsequent BlastN analyses indicated that the majority of isolated strains were Rlv [28].
Plasmid isolation from Rhizobium: Plasmid DNA was isolated by the method of [29].

Restriction fragment analysis: The extracted plasmids were digested with EcoRI and MSPI enzymes according to (Thermo scientific fermentase) as following: Combine the following reaction components at room temperature in order indicated: Water, nuclease-free $15 \mu \mathrm{l}, 10 \mathrm{x}$ FastDigest or 10x FastDigest Green Buffer $2 \mu$ l, DNA $2 \mu$, FastDigest enzyme $1 \mu \mathrm{l}$, Total volume $20 \mu \mathrm{l}$, Mix gently and spin down, incubate at $37^{\circ} \mathrm{C}$ in a heat block or water thermostat for (5-15) min and load an aliquot of the reaction mixture in $2 \%$ agarose with TBE (Tris -BoricEDTA) buffer. Electrophoreses were carried out at $100 \mathrm{~V}$ for $1 \mathrm{~h}$. Gels were stained with ethidium bromid"EtBr" $(2.5 \mathrm{mg} / 10 \mathrm{ml})$ and photographed under UV illumination.

\section{Statistical analysis}

The data were subjected to one-way ANOVA using SPSS (2002) analysis program (version 11.5). The significant differences among individual means were analyzed by Duncan's multiple range tests and statistical significance was determined at $5 \%$ level.

\section{Results and Discussion}

\section{Phenotypic characteristics}

On the basis of morphological parameters, we have confirmed differences between the isolates (Table 1) represent thirteen isolates of Rhizobium leguminosarum symbiovar Vicia isolated from nodules of Egyptian Faba beans (Vicia faba L.) collected from different geographic areas. This isolates were tested by Congo red technique according to [30]. To ensure that all isolates were rhizobia and did not contaminated. Rhizobial isolates were found to be microscopically similar, isolates identified as Rhizobium leguminosarium symbiovar. Vicia. According to the negative reaction to gram stain. Strains were found to be motile. On YEM agar, the growth is generally moist, whitish, smooth and gummy. Antibiotic resistance pattern: All isolates were evaluated for their responses as resistant or sensitive against 24 different antibiotic disks [24].

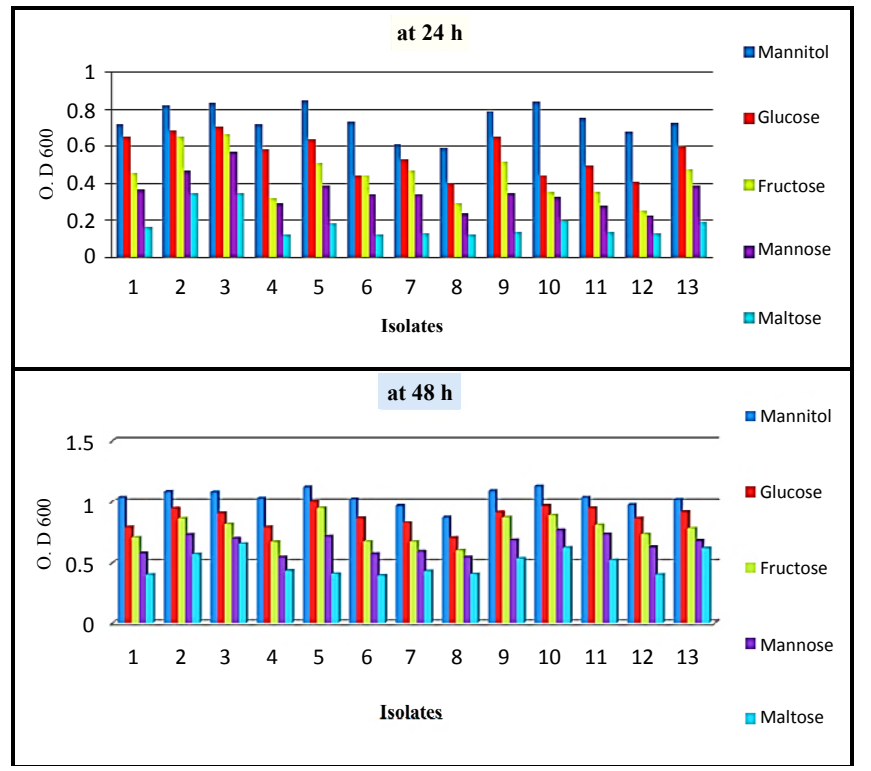

Figure 3: Effect of different carbon sources on growth of Rhizobium leguminosarumsv. Vicia on YEM broth medium after 24 and $48 \mathrm{~h}$ from inoculation. 
Citation: Elzanaty AM, Hewedy OA, Nagaty HH, Abd Elbary MI (2015) Molecular and Biochemical Characterization of Some Egyptian Genotypes Rhizobium (Vicia Faba) Isolates. J Bioengineer \& Biomedical Sci 5: 145. doi:10.4172/2155- 9538.1000145

Page 4 of 8

\begin{tabular}{|c|c|c|c|c|c|c|c|c|c|c|c|c|c|c|}
\hline \multirow{2}{*}{ Time (h) } & \multirow{2}{*}{$\begin{array}{l}\text { Carbon } \\
\text { Sources }\end{array}$} & \multicolumn{13}{|c|}{ Rhizobium leguminosarum sv. Vicia isolates } \\
\hline & & 1 & 2 & 3 & 4 & 5 & 6 & 7 & 8 & 9 & 10 & 11 & 12 & 13 \\
\hline \multirow{5}{*}{24} & Mannitol & $0.720 \mathrm{a}$ & $0.820 a$ & $0.836 a$ & $0.720 \mathrm{a}$ & $0.843 a$ & $0.730 \mathrm{a}$ & $0.611 \mathrm{a}$ & $0.589 a$ & $0.786 a$ & $0.838 a$ & $0.751 \mathrm{a}$ & $0.681 \mathrm{a}$ & $0.726 a$ \\
\hline & Glucose & $0.648 a$ & $0.686 a$ & $0.708 a b$ & $0.584 b$ & $0.634 b$ & $0.436 b$ & $0.528 a b$ & $0.395 b$ & $0.65 a b$ & $0.440 \mathrm{~b}$ & $0.492 b$ & $0.407 b$ & $0.598 a b$ \\
\hline & Fructose & $0.453 b$ & $0.649 a$ & $0.658 a b$ & $0.313 c$ & $0.505 \mathrm{bc}$ & $0.442 b$ & $0.465 b$ & $0.292 d$ & $0.512 b$ & $0.358 b$ & $0.354 \mathrm{c}$ & $0.254 c$ & $0.477 \mathrm{bc}$ \\
\hline & Mannose & $0.366 \mathrm{~b}$ & $0.466 \mathrm{~b}$ & $0.571 b$ & $0.290 c$ & $0.387 \mathrm{c}$ & $0.342 b$ & $0.341 \mathrm{c}$ & $0.236 \mathrm{~d}$ & $0.350 c$ & $0.323 b c$ & $0.276 c$ & $0.223 \mathrm{~cd}$ & $0.387 \mathrm{c}$ \\
\hline & Maltose & $0.162 c$ & $0.349 \mathrm{~b}$ & $0.349 c$ & $0.121 d$ & $0.183 d$ & $0.121 \mathrm{c}$ & $0.128 d$ & $0.121 \mathrm{c}$ & $0.133 d$ & $0.194 c$ & $0.134 d$ & $0.126 d$ & $0.184 d$ \\
\hline \multirow{5}{*}{48} & Mannitol & $1.039 a$ & $1.085 a$ & $1.081 a$ & $1.032 a$ & $1.120 a$ & $1.025 a$ & $0.966 a$ & $0.875 a$ & $1.092 a$ & $1.128 a$ & $1.040 a$ & $0.973 a$ & $1.022 a$ \\
\hline & Glucose & $0.789 \mathrm{~b}$ & $0.945 a b$ & $0.910 a b$ & $0.789 b$ & $1.00 \mathrm{a}$ & $0.871 \mathrm{ab}$ & $0.827 a b$ & $0.707 a b$ & $0.914 a b$ & $0.966 a b$ & $0.950 a b$ & $0.867 a b$ & $0.918 a b$ \\
\hline & Fructose & $0.708 \mathrm{bc}$ & $0.866 a b$ & $0.810 \mathrm{bc}$ & $0.673 \mathrm{bc}$ & $0.947 a b$ & $0.675 b c$ & $0.675 b c$ & $0.597 \mathrm{~b}$ & $0.875 a b$ & $0.890 \mathrm{ab}$ & $0.805 a b$ & $0.732 \mathrm{bc}$ & $0.779 b c$ \\
\hline & Mannose & $0.576 \mathrm{~cd}$ & $0.730 \mathrm{bc}$ & $0.700 \mathrm{bc}$ & $0.544 \mathrm{~cd}$ & $0.717 b$ & $0.570 \mathrm{~cd}$ & $0.59 \mathrm{~cd}$ & $0.544 \mathrm{bc}$ & $0.688 \mathrm{bc}$ & $0.765 b c$ & $0.735 b c$ & $0.623 c$ & $0.682 c$ \\
\hline & Maltose & $0.397 d$ & $0.568 c$ & $0.658 \mathrm{c}$ & $0.428 d$ & $0.405 c$ & $0.391 d$ & $0.426 d$ & $0.402 c$ & $0.533 c$ & $0.618 c$ & $0.521 \mathrm{c}$ & $0.398 d$ & $0.614 c$ \\
\hline
\end{tabular}

a, b, c=Means of each trait within each column don't have the same letter are significantly different significantly at 0.05 level

Table 2: Estimation Growth of Rhizobium leguminosarum sv. Vicia isolates using different carbon sources after 24 and 48 (h) from inoculation.

Growth rate at different carbon source: The results of carbohydrate utilization by Rhizobium are summarized in Table 2 and Figure 3. All the thirteen Rhizobium isolates were tested to utilize a wide range of carbohydrates as a sole carbon source. The Rhizobium isolates in this present study also preferred monosaccharides as well as mannitol for proper growth [31]. In the present study, the Rhizobium isolates from V. faba showed better growth with mannitol then glucose, fructose, mannose and maltose when mannitol was replaced with four other carbohydrates in equal quantities. Our results showed that Rhizobia prefer mannitol and glucose as best carbon sources for growth [32]. Furthermore all the tested isolates were able to utilize almost all tested carbon sources in this investigate. All of the isolates obtained from Vicia faba nodules were able to utilize mannitol, glucose, Fructose, Mannose and Maltose as carbon sources. These carbon sources are generally utilized by bacteria of the genus Rhizobium [33]. The ability of the isolates to utilize a broad range of carbon substrates is also related to the survival of the isolates under acidic environments. Generally, Mannitol and Glucose were the best source of carbon. Mannitol measurements were ranged from (O.D 1.128) with RL10 isolate followed by (O.D 1.120) with RL5 isolate to (O.D 0.875) with RL8, which showed the lowest growth among the studied isolates. Also Glucose measurements were ranged from (O.D 1.00) with RL5 isolate followed by (O.D 0.966) with RL10 isolate to (O.D 0.707) with RL8 (Figure 4). On other hand Maltose measurements were ranged from (O.D 0.658) with RL3 isolate followed by (O.D 0.618) with RL10 isolate to (O.D 0.391) with RL6.

\section{Roundup herbicide resistance test by agar plate and broth medium}

It is clear that the higher dose of Roundup herbicide inhibited the growth of Rhizobium and we observed varied growth in vitro under different herbicide treatments between the tested isolates. In broth culture method, untreated rhizobia (control) had the highest OD (Figure 5). The OD (240) recorded with lower concentration of Roundup with isolate No.11 compared with control. However, The OD (364) recorded with lower concentration of Roundup with isolates No.2 and No.3. Further to the OD (0.048) recorded with highest concentration of Roundup with isolate No.7. However, The OD (0.117) recorded with highest concentration of Roundup with isolate No.13. Compared with control (without Roundup Herbicide), whereas growth was visually grouped into 4 categories: +++ (good), ++ (moderate), + (poor) and - (no growth) at different concentration of $0,25,50,100 \mathrm{mg} /$ $\mathrm{ml}$ respectively in solid media (Tables 3 and 4). Growth inhibition was shown at highest concentration. Generally, the higher concentration of herbicide has higher toxicity to the bacteria. Therefore, the number of colonies tolerant to Roundup decreased when concentration increased. About $38 \%$ of isolates were tolerant to the higher concentration.

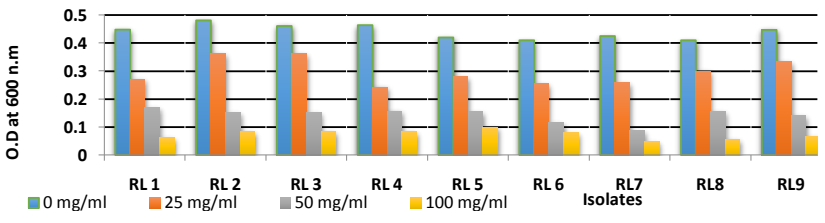

Figure 4: $O D \mathrm{~mm}$ of $\mathrm{R}$. leguminosarumsv .viciae isolates at different Concentrations of Roundup Herbicide after $72 \mathrm{~h}$ from inoculation.

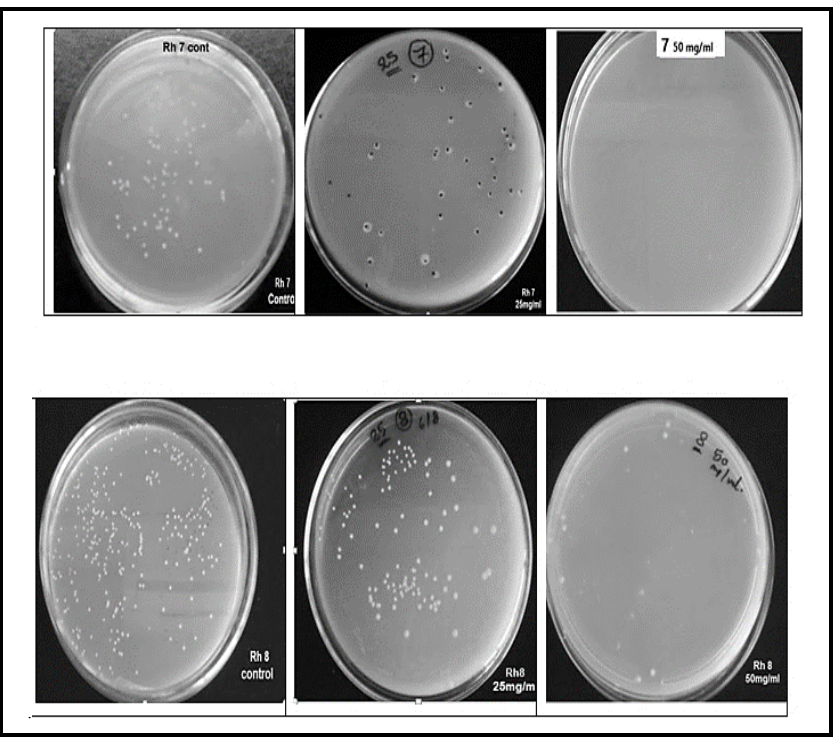

Figure 5: Isolates growing on YEMA media supplemented with different Roundup concentrations and control.

This experiment resulted in selected Rhizobium strains tolerant to environment stress i.e., high concentration of Roundup herbicide. Isolates from different locations in this study showed a great ability to degrade Roundup herbicide. They differed in their ability to Roundup degradation. It is clear that Ismailia City isolate was the most active degrading Roundup in this investigates as shown in Table 3. All isolates are tolerant to $25 \mathrm{mg} / \mathrm{ml}$ concentration of herbicide. All used isolates are very sensitive to $100 \mathrm{mg} / \mathrm{ml}$ concentration of herbicide and intermediate for $50 \mathrm{mg} / \mathrm{ml}$ concentration of herbicide. All Isolates showed inhibition of growth by increasing concentration of herbicide. All isolates grew on YEMA media [23]. The results of different 


\begin{tabular}{|l|l|l|l|l|}
\hline Isolate No. & \multirow{2}{*}{ Control } & \multicolumn{3}{|l|}{ Roundup herbicide } \\
\cline { 3 - 5 } & & $\mathbf{2 5} \mathbf{~ m g / m l}$ & $\mathbf{5 0 ~} \mathbf{m g} / \mathbf{m l}$ & $\mathbf{1 0 0} \mathbf{~ m g / m l}$ \\
\hline 1 & +++ & ++ & + & - \\
\hline 2 & +++ & ++ & + & - \\
\hline 3 & +++ & ++ & + & - \\
\hline 4 & +++ & ++ & + & - \\
\hline 5 & +++ & ++ & + & - \\
\hline 6 & +++ & ++ & + & - \\
\hline 7 & +++ & ++ & - & - \\
\hline 8 & +++ & ++ & + & - \\
\hline 9 & +++ & ++ & + & - \\
\hline 10 & +++ & ++ & + & - \\
\hline 11 & +++ & ++ & + & - \\
\hline 12 & +++ & ++ & + & - \\
\hline 13 & +++ & ++ & + & - \\
\hline
\end{tabular}

Whereas growth +++ (good), ++ (moderate), + (poor) and - (no growth)

Table 3: Response of Rhizobium isolates to different concentrations of Roundup herbicide.

\begin{tabular}{|l|l|l|l|l|}
\hline Isolates & \multicolumn{4}{l}{ Herbicide concentrations $\mathbf{~ g} / \mathbf{~ m l}$} \\
\cline { 2 - 4 } & $\mathbf{0}$ & $\mathbf{2 5}$ & $\mathbf{5 0}$ & 100 \\
\hline RL 1 & $0.448 \mathrm{a}$ & $0.271 \mathrm{bcd}$ & $0.171 \mathrm{abc}$ & $0.063 \mathrm{efg}$ \\
\hline RL 2 & $0.481 \mathrm{a}$ & $0.364 \mathrm{a}$ & $0.152 \mathrm{bcd}$ & $0.084 \mathrm{bcd}$ \\
\hline RL 3 & $0.461 \mathrm{a}$ & $0.364 \mathrm{a}$ & $0.152 \mathrm{bcd}$ & $0.084 \mathrm{bcd}$ \\
\hline RL 4 & $0.464 \mathrm{a}$ & $0.243 \mathrm{~d}$ & $0.157 \mathrm{abc}$ & $0.084 \mathrm{bcd}$ \\
\hline RL 5 & $0.420 \mathrm{a}$ & $0.280 \mathrm{bcd}$ & $0.154 \mathrm{bcd}$ & $0.100 \mathrm{ab}$ \\
\hline RL 6 & $0.410 \mathrm{a}$ & $0.254 \mathrm{~d}$ & $0.115 \mathrm{de}$ & $0.080 \mathrm{bcde}$ \\
\hline RL 7 & $0.425 \mathrm{a}$ & $0.260 \mathrm{~cd}$ & $0.088 \mathrm{e}$ & $0.048 \mathrm{~g}$ \\
\hline RL 8 & $0.410 \mathrm{a}$ & $0.300 \mathrm{abcd}$ & $0.155 \mathrm{abc}$ & $0.057 \mathrm{fg}$ \\
\hline RL 9 & $0.447 \mathrm{a}$ & $0.334 \mathrm{abc}$ & $0.140 \mathrm{~cd}$ & $0.067 \mathrm{defg}$ \\
\hline RL 10 & $0.475 \mathrm{a}$ & $0.340 \mathrm{ab}$ & $0.178 \mathrm{abc}$ & $0.090 \mathrm{bc}$ \\
\hline RL 11 & $0.431 \mathrm{a}$ & $0.240 \mathrm{~d}$ & $0.154 \mathrm{bcd}$ & $0.080 \mathrm{bcde}$ \\
\hline RL 12 & $0.480 \mathrm{a}$ & $0.251 \mathrm{~d}$ & $0.194 \mathrm{a}$ & $0.070 \mathrm{cdef}$ \\
\hline RL 13 & $0.500 \mathrm{a}$ & $0.341 \mathrm{ab}$ & $0.184 \mathrm{ab}$ & $0.117 \mathrm{a}$ \\
\hline
\end{tabular}

$a, b, c=$ Means of each trait within each column don't have the same letter are significantly different at 0.05 level (Same Colum)

Table 4: Effect of herbicides on growth after $72 \mathrm{hr}$. (measured as optical density) of Rhizobium isolates.

concentrations of herbicide effects on Rhizobial growth showed that 25 $\mathrm{mg} / \mathrm{ml}$ concentration was the best concentration for all isolates growth; there was no growth at all at $100 \mathrm{mg} / \mathrm{ml}$ for all isolates. As consequently different concentrations of herbicide decrease in the growth of rhizobia untreated rhizobia had the highest O.D. and each successive increase in the concentration of herbicide decreased the O.D. These results are in agreement with those obtained by [9] who studied the effect of different herbicides on the nodulation and growth of Rhizobial isolates. Also some studies have evaluated the effect of different herbicides on Rhizobium growth and nitrogen fixation activity. The effect depends on the herbicide, its concentration, and different weather conditions. Applied research methodology also may depend on the Rhizobium or Bradyrhizobium species and even the strain used [34].

\section{Biochemical identification of rhizobia}

IAA production: All isolated Rhizobia showed variations in red colour reaction with salkowaski reagent indicating their variations ability to produce IAA. Comparison between the isolated Rhizobia showed variation for their ability to produce IAA. Rhizobium isolates from Vicia faba differ in IAA production. In majority of isolates; the amount of IAA produced was more than that in the control. The maximum amount of IAA production was in the range of 2.04 for isolate No.8 from Al Arish City to $7.5 \mu \mathrm{g} / \mathrm{ml}$ for isolate No.13 from Ismailia City in all the isolates studied. Comparison of means shows that there is a difference between isolates. Indole -3-acetic acid (IAA) is the common natural auxin, to produce auxin. This substance can be converted to IAA by soil beneficial bacterial activities. Tryptophan (L-trp) is physiologically a precursor of auxin biosynthesis in higher plants and microorganism [35]. Various reports showed Tryptophan derived microbial auxins present in the rhizosphere area play a very important role in growth and development of plant rooting system and crop yield [36]. Many of rhizobial species enable to produce IAA. Some studies shows that auxins play a key role in creating nodule in leguminous plants and generally, in establishing a symbiotic association with rhizobia. Also has been proved that flavonoids, promoting nodulation gene, increase the production of IAA by rhizobial bacteria [37]. Rhizobia are known to produce significant levels of IAA both in free living conditions and also symbiotically in nodules [38], (Table 5 and Figure 6).

Catalase test: Results present in Table 6 and Figure 7 revealed that the biochemical characteristics of Rhizobium isolates showed positive production of Catalase enzyme, by all of the tested isolates with exception of isolate RL 3 and RL 12. The genetic diversity among thirteen isolates representing the indigenous population of rhizobia was investigated using SDS-PAGE pattern. SDS-PAGE profile of protein extracted from thirteen R. leguminosarum isolates (Table 7 , Figures 8 and 9). A dendrogram developed from similarity between the

\begin{tabular}{|c|c|c|}
\hline Bacterial isolates & IAA Production $(\boldsymbol{\mu g} / \mathbf{m l})$ & O.D at $\mathbf{5 3 0} \mathbf{~ n m}$ \\
\hline 1 & 3.18 & 0.057 \\
\hline 2 & 3.47 & 0.063 \\
\hline 3 & 4.56 & 0.086 \\
\hline 4 & 4.13 & 0.077 \\
\hline 5 & 3.50 & 0.065 \\
\hline 6 & 3.30 & 0.056 \\
\hline 8 & 3.20 & 0.058 \\
\hline 9 & 2.04 & 0.033 \\
\hline 10 & 3.30 & 0.060 \\
\hline 11 & 2.30 & 0.039 \\
\hline 12 & 4.90 & 0.094 \\
\hline 13 & 6.57 & 0.128 \\
\hline control & 7.50 & 0.148 \\
\hline
\end{tabular}

Table 5: Mean comparison of IAA production Bacterial isolates using O.D.

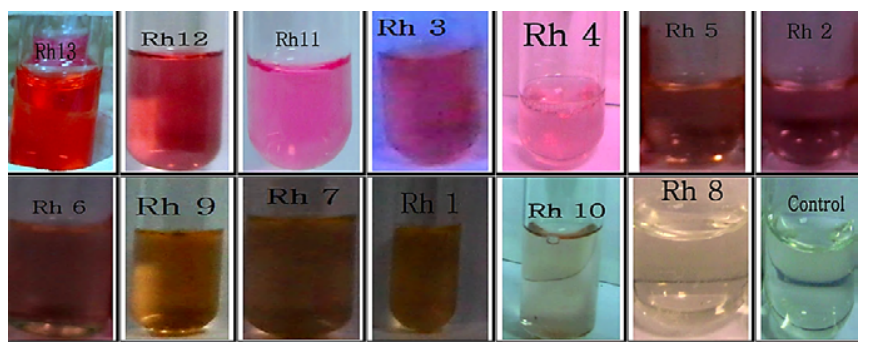

Figure 6: IAA production assay of the bacterial isolates in vitro by Salkowski assay. 
Citation: Elzanaty AM, Hewedy OA, Nagaty HH, Abd Elbary MI (2015) Molecular and Biochemical Characterization of Some Egyptian Genotypes Rhizobium (Vicia Faba) Isolates. J Bioengineer \& Biomedical Sci 5: 145. doi:10.4172/2155- 9538.1000145

Page 6 of 8

\begin{tabular}{|c|c|c|c|c|c|c|c|c|c|c|c|c|}
\hline \multicolumn{13}{|c|}{ Rhizobial isolates } \\
\hline $\mathrm{RL} 1$ & RL 2 & RL 3 & $\mathrm{RL} 4$ & RL 5 & RL 6 & RL 7 & RL 8 & RL 9 & RL 10 & RL 11 & RL 12 & RL 13 \\
\hline+ & + & - & + & + & + & + & + & + & - & + & - & + \\
\hline
\end{tabular}

Whereas, (+) means resistance and (-) means sensitive

Table 6: Effect of different isolates on Catalase production

\begin{tabular}{|c|c|c|c|c|c|c|c|c|c|c|c|c|}
\hline Rh1 & Rh2 & Rh3 & Rh4 & Rh5 & Rh6 & Rh7 & Rh8 & Rh9 & Rh10 & Rh11 & Rh12 & Rh13 \\
\hline \multicolumn{13}{|l|}{1.00} \\
\hline 1.00 & 1.00 & & & & & & & & & & & \\
\hline 1.00 & 1.00 & 1.00 & & & & & & & & & & \\
\hline 0.90 & 0.90 & 0.90 & 1.00 & & & & & & & & & \\
\hline 1.00 & 1.00 & 1.00 & 0.90 & 1.00 & & & & & & & & \\
\hline 1.00 & 1.00 & 0.90 & 1.00 & 1.00 & 1.00 & & & & & & & \\
\hline 1.00 & 1.00 & 1.00 & 0.90 & 1.00 & 0.81 & 1.00 & & & & & & \\
\hline 0.81 & 0.81 & 0.81 & 0.72 & 0.81 & 0.90 & 0.81 & 1.00 & & & & & \\
\hline 0.90 & 0.90 & 0.90 & 0.81 & 0.90 & 1.00 & 0.90 & 0.90 & 1.00 & & & & \\
\hline 1.00 & 1.00 & 1.00 & 0.90 & 1.00 & 1.00 & 1.00 & 0.81 & 0.90 & 1.00 & & & \\
\hline 1.00 & 1.00 & 1.00 & 0.90 & 1.00 & 1.00 & 1.00 & 0.81 & 0.90 & 1.00 & 1.00 & & \\
\hline 1.00 & 1.00 & 1.00 & 0.90 & 1.00 & 1.00 & 1.00 & 0.81 & 0.90 & 1.00 & 1.00 & 1.00 & \\
\hline 1.00 & 1.00 & 1.00 & 0.90 & 1.00 & 1.00 & 1.00 & 0.81 & 0.90 & 1.00 & 1.00 & 1.00 & 1.00 \\
\hline
\end{tabular}

Table 7: Similarity between different tested isolates based on Protein banding pattern analyses.

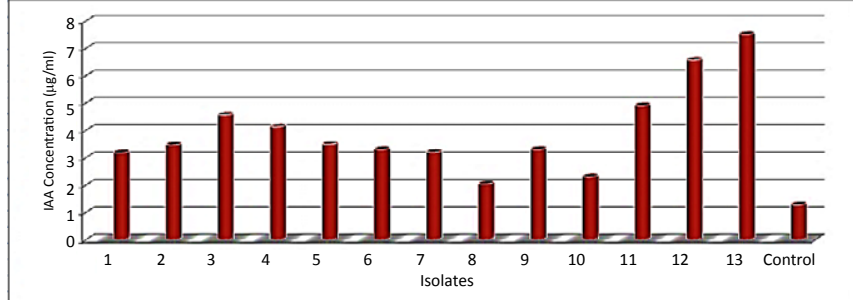

Figure 7: Estimation IAA production using optical density.
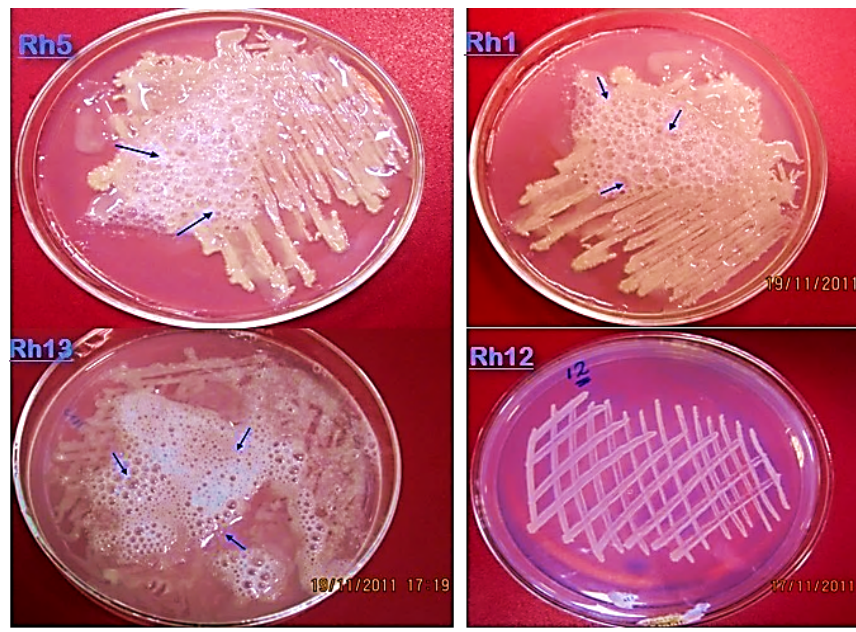

Figure 8: Estimation catalase production using $\mathrm{H}_{2} \mathrm{O}_{2}$. Protein banding pattern of thirteen Rhizobial isolates.

different isolates based on Protein banding pattern formed two groups of proteins were identified in Rhizobium leguminosarum sv viciae isolates (Table 8). The first group contained eleven isolates, whereas the second group contained remains isolates RL8 and RL9 located in South and North Sinai respectively. It showed a total of 78 bands with different molecular weight values ranged from 130 to $15 \mathrm{KDa}$. The protein bands of the tested isolates varied in numbers of bands.

\begin{tabular}{|l|l|l|l|l|} 
Isolate No. & Control & \multicolumn{3}{|l|}{ Roundup herbicide } \\
\cline { 3 - 5 } & & $\mathbf{2 5} \mathbf{~ m g / m l}$ & $\mathbf{5 0} \mathbf{~ m g / m l}$ & $\mathbf{1 0 0} \mathbf{~ m g / m l}$ \\
\hline 1 & 120 & 50 & 30 & 0 \\
\hline 2 & 140 & 40 & 30 & 0 \\
\hline 3 & 100 & 40 & 30 & 0 \\
\hline 4 & 130 & 50 & 30 & 0 \\
\hline 5 & 120 & 70 & 40 & 0 \\
\hline 6 & 120 & 80 & 60 & 0 \\
\hline 7 & 70 & 36 & 0 & 0 \\
\hline 8 & 120 & 100 & 40 & 0 \\
\hline 9 & 140 & 30 & 30 & 0 \\
\hline 10 & 150 & 80 & 50 & 0 \\
\hline 11 & 100 & 50 & 30 & 0 \\
\hline 12 & 120 & 50 & 30 & 0 \\
\hline 13 & 150 & 90 & 50 & 0 \\
\hline
\end{tabular}

Table 8: Effect of different concentrations of Roundup herbicide on number of colonies at Rhizobium Leguminosarum sv.vicia (107cells $\mathrm{ml}^{-1}$ ).

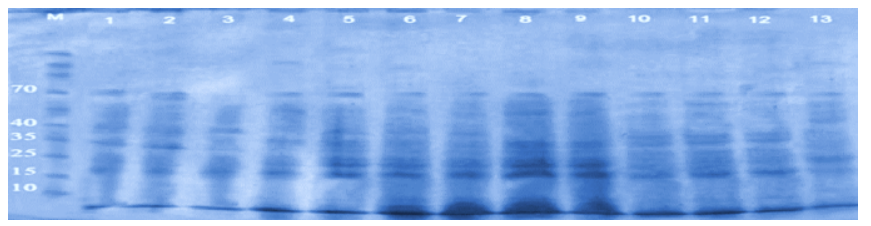

Figure 9: Stained SDS-PAGE pattern of total soluble protein of thirteen Rhizobial isolates from different locations. $\mathrm{M}$, molecular weight standard (PageRulerTM protein ladder, Fermentas).

The electrophoresis banding pattern of thirteen R. leguminosarum isolates showed either absence or presence of different polypeptides in this study. One band was for only one isolate RL4 (130 KDa), some of these bands appeared in each of the studied isolates such as 70,40 , $35,25,20$ and $15 \mathrm{KDa}$ which were considered monomorphic bands. Whereas each isolate contained at protein banding range 5-7 bands. Our results were agreement with [39] who mentioned that protein patterns, peroxides isozymes and DNA fingerprints were used for analysis of somaclonal variations among three R. leguminosarum 
Citation: Elzanaty AM, Hewedy OA, Nagaty HH, Abd Elbary MI (2015) Molecular and Biochemical Characterization of Some Egyptian Genotypes Rhizobium (Vicia Faba) Isolates. J Bioengineer \& Biomedical Sci 5: 145. doi:10.4172/2155- 9538.1000145

isolates to determine Rhizobium genetic diversity under environment stress. Preparation of total protein from all rhizobial isolates showed seventy eight bands ranged from $(15$ to $130 \mathrm{KD})$, these bands were not necessarily present in all isolates. Among tested Rhizobium isolates there were some variations in protein banding pattern. As presented in Figure 10. There were sixty five bands common in all Rhizobial isolates and thirteen bands showed variability among them. This is may be due to the differences of their genetic background according to the different locations; similar conclusion was also obtained by [40] who stated that Rhizobial isolates could be distinguished by protein banding pattern. Our results indicate that under salt stress, SDS-PAGE revealed a powerful characterization of method Rhizobium leguminosarium genotypes. On the other hand, phenotypic and genotypic diversity among tested strains play important role for their tolerance or sensitive stress. The results finding is in agreement with [41] that used protein pattern to analyze the genetic variations among three Rhizobium leguminosarum and observed variation in protein banding pattern $(10$, 12 and 11 polypeptide bands). This study was conducted to employ SDS-PAGE as simple tool to determine the genetic variability among R. leguminosarum isolates (Figure 11).

\section{Plasmid isolation from Rhizobium}

Plasmid profile of Rhizobial isolates were presented in Figure 12. Results showed variation in number of bands based on variation in size

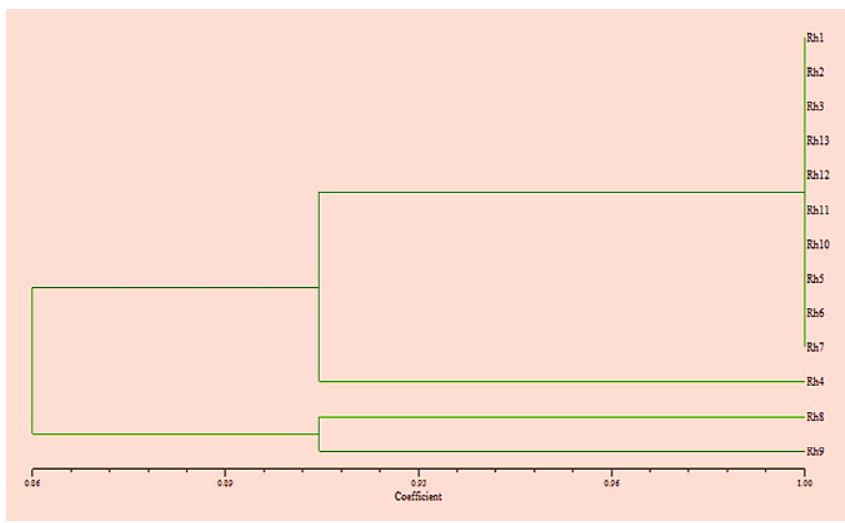

Figure 10: Phylogenetic relationship between 13 Rhizobial isolates using UPGMA method based on Protein banding pattern analyses.

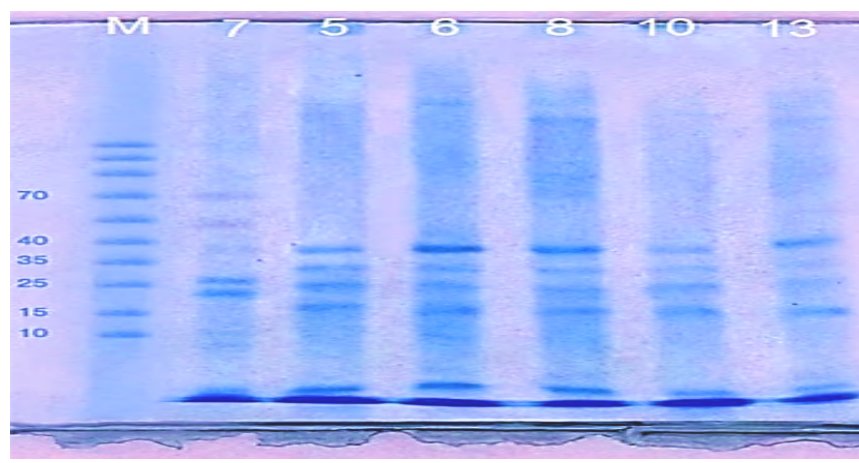

Figure 11: Stained SDS-PAGE pattern of total soluble protein in RL.7, 5, 6 , 8,10 and 13 grown in YEM medium and incubated with $50 \mathrm{mg} / \mathrm{ml}$ Roundup herbicide concentration, sensitive isolate (lane 7) and tolerant isolates (lane 5 $6,8,10$ and 13), M, molecular weight standard (PageRulerTM protein ladder, Fermentas).
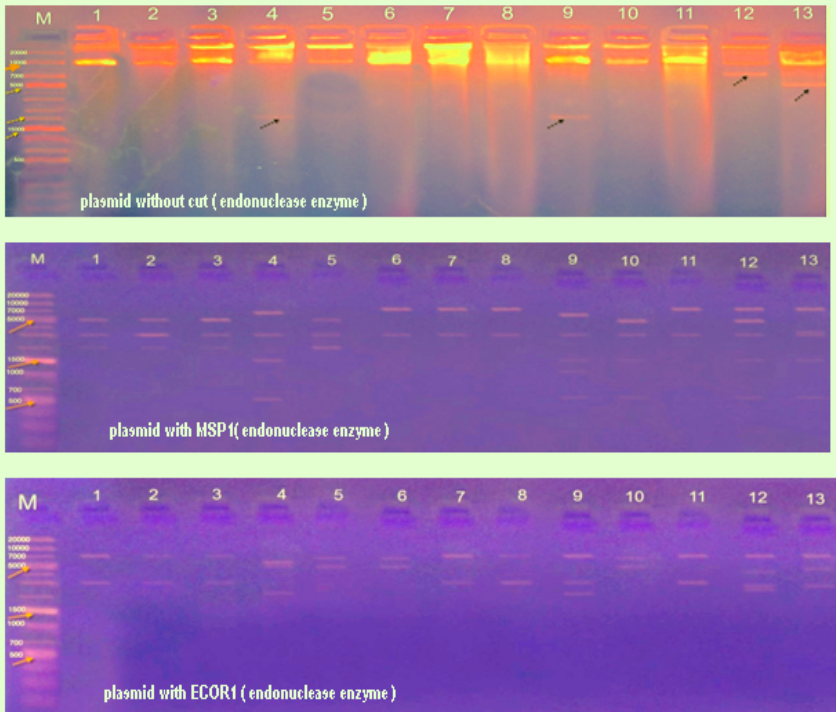

Figure 12: Plasmid profile of tested Rhizobial isolates.

of plasmids. Plasmid genotypes of rhizobia nodulating Faba bean from various Egyptian locations were extracted and characterized. Plasmid profile analysis revealed different plasmid types having differ of size ranging from 10 to $0.5 \mathrm{~Kb}$ pairs. A variation in number of symbiotic (Sym) plasmid was observed. The size of these plasmids showed marked diversity among the isolates and varied in size from 10 to 0.5 $\mathrm{Kbp}$. Isolates were characterized according to their plasmid profiles. All studied isolates contained a $10 \mathrm{Kbp}$ plasmid and four isolates RL4, RL9, RL12 and RL13 contained additional small plasmid with molecular weight about $2 \mathrm{Kbp}, 2 \mathrm{Kbp}, 7 \mathrm{Kbp}$ and $5 \mathrm{Kbp}$ respectively as shown in Figure 12. These data are parallel to that achieved by [42-44] who found that R. leguminosarum sv. Viciae strain T83K3 which had six plasmids of $480,440,300,255,210$ and $155 \mathrm{~kb}$.

\section{Conclusion}

This research determines the phenotypic diversity of the rhizobia that nodulates Vicia faba through their growth characteristics, e.g. carbon source utilization. This could lead to an improvement in the selection of strains that efficiently nodulate and fix nitrogen and may be used as inoculants for their host plant.

\section{References}

1. Zakhia F, de Lajudie P (2001) Taxonomy of rhizobia, Agronomie 21: 569-576.

2. AM Hirsh (1992) Developmental biology of legume nodulation, New Phytol 122 211-237.

3. Requena N, Perez-Solis E, Azcon-Aquilar C, Jeffries P, Barea JM (2001) Management of indigenous plant-microbe symbioses aids restoration of decertified ecosystems. Appl Environ Microbiol 67: 495-498.

4. Glick BR (2012) Plant growth-promoting bacteria: mechanisms and applications, Hindawi Publishing Corporation.

5. Batut J, Mergaert P, Masson-Boivin C (2011) Peptide signalling in the Rhizobium-legume symbiosis. Curr Opin Microbiol 14: 181-187.

6. Kim J, Rees DC (1994) Nitrogenase and biological nitrogen fixation. Biochem 33: 389-397.

7. Ladha JK, de Bruijn FJ, Malik KA (1997) Introduction: Assessing opportunities for nitrogen fixation in rice-a frontier project. Plant Soil 194: 1-10.

8. Hartmann M, Fliessbach A, Oberholzer HR, Widmer F (2006) Ranking of crop 
Citation: Elzanaty AM, Hewedy OA, Nagaty HH, Abd Elbary MI (2015) Molecular and Biochemical Characterization of Some Egyptian Genotypes Rhizobium (Vicia Faba) Isolates. J Bioengineer \& Biomedical Sci 5: 145. doi:10.4172/2155- 9538.1000145

and long term farming system effects based on soil bacterial genetic profiles. FEMS Microbiol Ecol 57: 378-388

9. Shankar PV, NR Shaikh, PS Vishwas (2012) Effect of Different Herbicides on the Nodulation Property of Rhizobial Isolates. Uni J Environ Res and Tech 2 : 293-299.

10. Anderson A, Baldock JA, Rogers SL, Bellotti W, Gill G (2004) Influence of chlorsulfuron on Rhizobial growth, nodule formation, and nitrogen fixation with chickpea, Aust J Agric Res 55: 1059-1070.

11. Ahemad M, Khan MS (2012) Effects of pesticides on plant growth promoting traits of Mesorhizobium strain MRC4, J Saudi Society Agric Sci 11: 63-71.

12. Kumar N, Anubhuti Bora JI, Amb MK (2010) Chronic toxicity of the triazole fungicide tebuconazole on a heterocystous, nitrogen-fixing rice paddy field cyanobacterium, Westiellopsis prolifica Janet. J Microbiol Biotechnol 20: 11341139

13. Fox JE, Gulledge J, Engelhaupt E, Burow ME, McLachlan JA (2007) Pesticides reduce symbiotic efficiency of nitrogen-fixing rhizobia and host plants. PNAS 104: 10282-10287.

14. Musarrat J, Haseeb A (2000) Agrichemicals as antagonist of lectin-mediated Rhizobium-legume symbiosis: Paradigms and prospects. Curr Sci 78: 793-797.

15. Clark SA, Mahanty HK (1991) Influence of herbicides on growth and nodulation of white clover, Trifolium repens. Soil Biology and Biochemistry 23: 725-730.

16. Saxena D, M Amin, S Khanna (1996) Modulation of protein profiles in Rhizobium spp. under salt stress. Can J Microbiol 42: 617-620.

17. Wankhade S, SK Apte, KK Rao (1996) Salinity and osmotic stress regulated proteins in cowpea Rhizobium 4a (peanut isolate). Biochem Molecular Biol Inter 39: 621-628.

18. Roberts GP, WT Leps, LE Silver, WJ Brill (1980) Use of two dimensions polyacralamide gel electrophoresis to identify and classify Rhizobium strains. Appl Environ Microbiol 39: 414-422.

19. Fabriano E, A Arias (1990) Identification of inoculants strains and naturalized population of Rhizobium leguminosarum bv. trifolii using complementary methodologies. World J Bacteriol Biotechnol 6: 127-143.

20. Broughton WJ, U Samrey, J Stanely (1987) Ecological genetics of Rhizobium meliloti: Symbiotic plasmid transfer in the Medicago sativa rhizosphere. FEMS Microbiol Lett 40: 251-255.

21. Long SR (1989) Rhizobium genetics. Annu Rev Genet 23: 483-506.

22. Corich V, A Giacomini M, Carlot R, Simon HV, Tichy A, et al. (2001) Comparative strain typing of Rhizobium leguminosarum sv. Viciae natural populations Can J Microbiol 47: 580-584.

23. Vincent JM (1970) A Manual for the Practical Study of Root-Nodule Bacteria IBP Handbook no. 15. Oxford: Blackwell Scientific Publications.

24. Hewedy OA, Ragaa A. Eissa, Elzanaty AM, HH Nagaty (2014) Phenotypic and Genotypic Diversity of Rhizobia Nodulating Faba Bean from Various Egyptian Locations. J Bioproces Biotechniq 4: 170-178.

25. Gordon A, Weber R (1951) Colorimetric estimation of indole acetic acid. Plant Physiol 26: 192-195

26. Laemmli UK (1970) Cleavage of Structural Proteins during the Assembly of the Head of Bacteriophage T4. Nature 227: 680-685.

27. Ausubel FM, Brent R, Kingston RE, Moore DD, Seidman JG, et al. (1987) Current protocols in molecular biology. John Wiley and Sons, Inc, New York.

28. Ismail M, El-Zanatay AM, RA Eissa, Hewedy OA (2013) Genetic Diversity of Rhizobium leguminosarum as Revealed by $16 \mathrm{~S}$ rRNA Gene Sequence. American-Eur. J Agric Environ Sci 13: 797-801.

29. Birnboim HC, Doly J (1979) A Rapid Alkaline Extraction Procedure for Screening Recombinant Plasmid DNA. Nucleic Acids Res 7: 1513-1523.

30. Hahn NJ (1966) The Congo red reaction in bacteria and its usefulness in the identification of Rhizobia. Can J Microbiol 12: 725-733
31. Cigdem K, Kivanc M, Engin K (2006) Characterization of Rhizobium sp. isolated from bean. Turk J Biol 30: 127-132.

32. Fred EB, IL Baldwin, Mc E Coy (1932) Root nodule bacteria and leguminous plants. Studies in Science, 5.Uni.Wisconsin Press, Madison, 343.

33. Stowers MD (1985) Carbon metabolism in Rhizobium species. Ann Rev Microbiol 39: 89-108

34. Sprout SL, Nelson L, Germida JJ (1992) Influence of metribuzin on the Rhizobium leguminosarum lentil (Lens culinaris) symbiosis. Can J Microbio 38: $343-349$

35. Spaenpen S, Vanderleyden J, Remans R (2007) Indole-3-acetic acid in microbial and microorganism plant signaling. FEMS Microbiol 31: 425-448.

36. Vanloon LC, PAHM Bakker (2003) Signaling in Rhizobacteria-plant interactions Ecological Studies, 168: 301-330.

37. Neeru N, Vivek K, Rishi K, Wolfgancy M (2000) Effect of P-solubilizing Azotobacter chroococcumon N, P, K uptake in p-responsive genotypes grown under greenhouse condition. J Plant Nutr Soil Sci 163: 393-398.

38. Ernstsen A, Sandberg G, Crozier A, Wheeler CT (1987) Endogenous indoles and the biosynthesis and metabolism of indole -3-acetic acid in cultures of Rhizobium phaseoli. Planta 171: 422-428.

39. Amer MM (2008) Monitoring of variation among Faba bean Rhizobium isolates: 2. Biodegradation of herbicide 3 (3, 4-dichlorophenyl)-1-methoxy-1-methyl urea. J Appl Sci Res 2: 540-548.

40. Feng QW, ET Wang, FZ Yong, WX Chen (2006) Characterization of Rhizobia isolated from Albizia spp. in comparison with microsymbionts of Acacia spp. and Leucaena leucocephala grown in China. Sys Appl Microbiol 29: 502-517.

41. Mohamed HF, TA Nor El Din, EH Abdel-Shakour, KA El-Dougdoug (2011) Detection of Genetic Variation among Three Isolates of $R$. leguminosarum Using Protein, Isozyme and DNA Fingerprints. J Am Sci 7: 435-440.

42. Wang CL, JE Beringer, PR Hirsch (1986) Host plant effects on hybrids of Rhizobium leguminosarum symbiovars viciae and trifolii. J General Microbio 132: $2063-2070$

43. Foo KY, Hameed BH (2010) Detoxification of pesticide waste via activated carbon adsorption process, J Hazard Mate 175: 1-11.

44. Somasegaran P, Hoben HJ (1994) Handbook for Rhizobia: Methods in Legume-Rhizobium Technology: Springer-Verlag, New York. 